\title{
Map Margin Information
}

\section{Ever wonder what all those little numbers are on the borders of your map? Here are the facts...}

1 State plane coordinate system -660,000 feet north from origin within the state plane grid system.

This coordinate system was established by the U.S. Coast and Geodetic Survey for use in defining positions of points in terms of plane rectangular $(\mathrm{x}, \mathrm{y})$ coordinates. There is usually one system for each state and each state determines the measurement unit (i.e., feet or meters).

2 Latitude -- 39 degrees, 37 minutes, 30 seconds (north of the Equator, which is at 0 degrees latitude).

3 Longitude -- 105 degrees, 15 minutes, 00 seconds (west of Meridian of Greenwich, also called Prime Meridian, which is at 0 degrees longitude).

4 North American Datum of 1927 -- horizontal datum. Required for GPS users. Also identifies UTM zone and state plane coordinate system.

5 GN -- UTM grid north (at the center of the map).

6 State plane coordinate system -$2,080,000$ feet east of origin.

$7 \star$-- true or geographic north -points to the north geographic pole.

$8 \mathrm{MN}$-- magnetic north -- the approximate direction (at the center of the map) to the north magnetic pole at the date given, in this case 1994. The direction to which a magnetic compass needle points. $911^{\circ}$ east -- magnetic declination or variation of the compass -the number of degrees a compass needle at a particular location bears away from true north and points to the north magnetic pole. 196 MILS -military angular measurement.

10 Longitude again -- this is a 2.5 minute geographic grid tick 105 degrees (understood), 12 minutes, 30 seconds west.

11 Adjoining USGS quadrangle name "Indian Hills." The notation "4963 II SW" is the NGA (National GeospatialIntelligence Agency, the Department of Defense mapping agency) sheet designator for the same map.

12 Range 69 West -- $69^{\text {th }}$ range west of 6th Principal Meridian (which is at Meades Ranch, Kansas).

Public Land Subdivisions: In 1785 Congress adopted a plan for surveying public lands. According to this plan, land was divided into townships approximately 6 miles square, which were further subdivided into 36 sections approximately 1 mile square. Principal meridians and base lines were established as a reference system for the township surveys.

13 UTM (Universal Transverse Mercator) easting value -486,000 meters false easting (last 3 zeroes omitted for brevity) (Zone13).

14 UTM easting value $-488,000$ meters false easting (Zone 13).
15 Map reference code: 39 - degrees north latitude 105 - degrees west longitude F2 -- index number (area reference code) $\mathrm{TF}$-- Topo map with contour values in Feet 024 -- 1:24,000 scale

16 ISBN number - International Standard Book Number.

17 UTM northing value -$4,387,000$ meters north from the Equator. "Northings" in the southern hemisphere begin with the Equator value $=10,000,000$ meters and decrease in value.

18 Section number 5. See Public Land Subdivisions.

19 Township 4 South -- 4 townships south of base line (Base Line of 1855, in this case). See Public Land Subdivisions.

20 Latitude again - another 2.5 minute grid tick - 39 degrees (understood), 40 minutes, 00 seconds.

\section{Additional Information}

For information on other USGS products and services, call 1-888ASK-USGS or use the ASK.USGS fax service, which is available 24 hours a day at 703-648-4888.

Please visit the USGS home page at www.usgs.gov. 


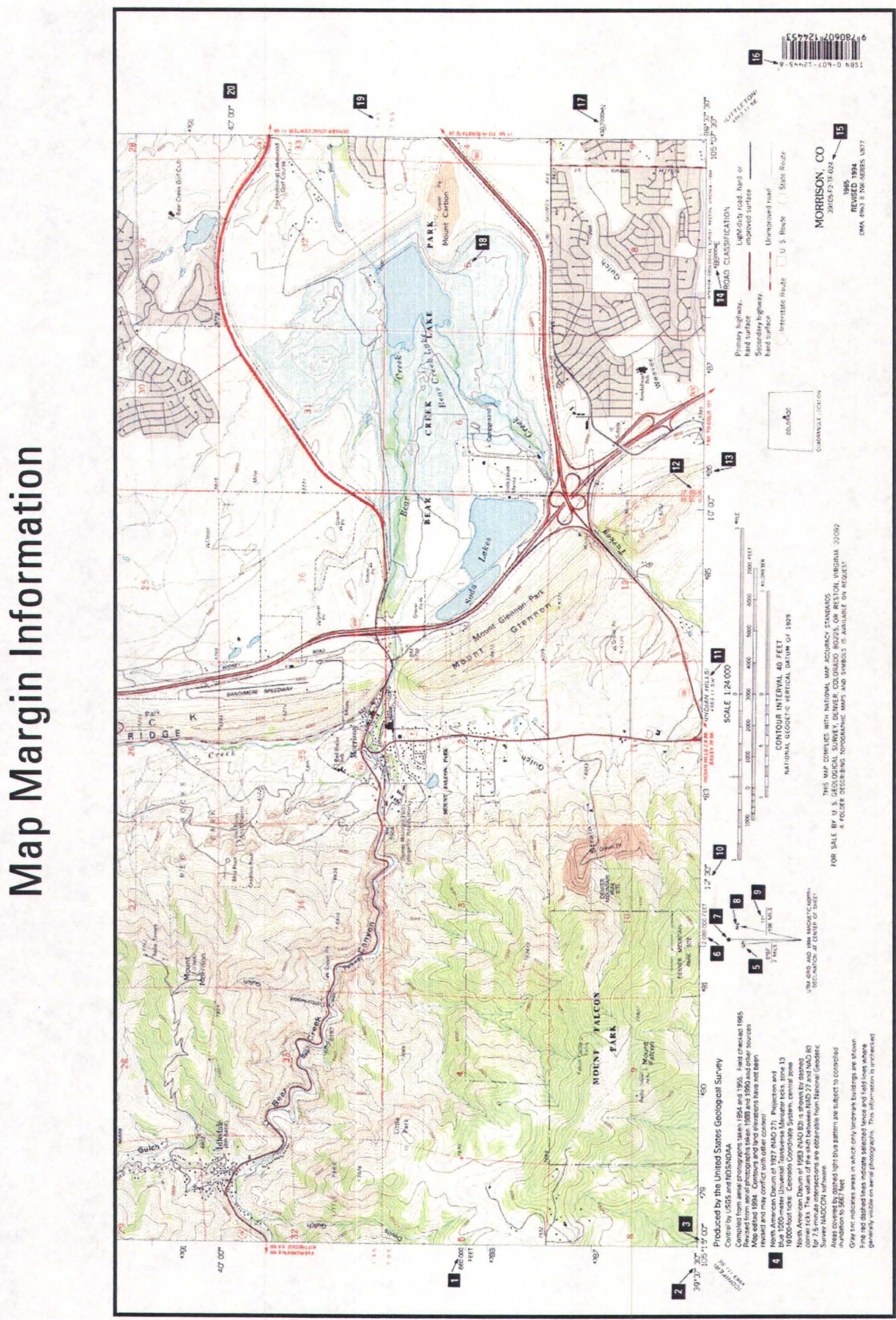

